\title{
Research on Talent Demand of Business English under the Background of Free Trade Zone in China
}

\author{
Xue Dong ${ }^{1, \text { a }}$ \\ ${ }^{1}$ Xi’an FanYi University, Xi’an, 710105, China
}

Keywords: Talent demand, Business English, Free trade zone

\begin{abstract}
China has approved the establishment of twelve free trade zones by 2017, which not only involve the coastal areas but also involve the inland areas. The construction of free trade zones requires the cultivation of many business English talents. This paper analyzes the demand for business English talents in the free trade zones, and gives suggestions for the training model of business English talents in the context of free trade zones to provide some references for the relative researchers.
\end{abstract}

\section{Introduction}

The accelerated development of economic globalization and China's more free trade area built, to promote the social demand for composite business English talent is increasing, especially the expansion of legal knowledge, familiar with foreign trade, foreign trade business operation in the demand of English application and computer operating personnel, this is undoubtedly the development of regional economy and higher education development business direction. In this situation, College English majors to open business courses, management or professional English training efforts continue to increase, or setting up business English majors to cultivate English language ability and knowledge of international trade business English talents. As an interdisciplinary subject, business English pays equal attention to international business knowledge and English language skills, considers both the importance of language and professional knowledge, and highlights language communication in international business environment. The quality of business English talents of enterprise talent supply, promote the business development of enterprises, at the same time, the introduction of foreign enterprises of the advanced management concept, expand the channels to enhance the international competitiveness in the international market, also played a crucial role. English talent helps to improve the investment environment and enhance popularity. It is foreseeable that many enterprises will be settled in the free trade zone in the future. The government should make efforts to improve the investment environment. In addition to beautifying the city, improving administrative efficiency and paying attention to the latter services, the government will pay more attention to the introduction, training and use of talents, especially English talents. This is because companies need compound English talents. To a certain extent, English talents play an important role in the enterprise. Excellent English talents can promote the development of enterprises and improve the investment environment. The English talent can not only help improve the investment environment, but also because of its link role, foreign companies can further understand the development environment of free trade zones. In addition, we can also introduce advanced technology and management experience of foreign companies to improve the international reputation and reputation of free trade zones.

\section{Demand of Free Trade Zones in China for Business English talents}

Good Language Ability. For a long time, foreign language teaching in Colleges and universities in our country has paid too much attention to the training of basic language skills, while neglecting the cultivation of students' language ability. The traditional English teaching contents and teaching 
methods, we are still too much emphasis on vocabulary and correct grammar and the teaching of language knowledge, while ignoring the students' ability to use the language, culture or language communicative competence. Even if the students' vocabulary again, because of the lack of language ability, once at the critical moment, you will not find the application of lexical expression accurate and precise, often due to the influence of the quality of translation, thus restricting the substance of business negotiation. It is generally believed that employees' listening and speaking ability and translation ability are more important than writing ability and reading ability. Most enterprises consider it necessary or necessary to learn a second foreign language. English is the prerequisite. Compared with domestic e-commerce, cross-border e-commerce transactions are not the face of their own language users, English is the necessary means of communication for all external transactions. This is also the core competitiveness of business English majors competing in cross-border e-commerce positions. Therefore, English listening, speaking, reading, writing and translating ability are still the major of business English. Relying on e-commerce platform for business contacts, but also need to strengthen the ability to write foreign trade correspondence and English product information reading and translation capabilities. In the free trade zone, many foreign business people will come in and need to communicate with people with good English skills. At present, some English majors are good at reading and writing, but lack of listening and speaking ability. This ability only English personnel cannot meet the needs of the free trade zones of business English talents.

Competent Business Qualifications. Business English talent services are operational service industry, whether it is tourism management, exhibition organization or business process, require that they have a strong ability to obtain information to solve the problem of using ability, practical ability, organization and coordination ability and analysis, so that they can take charge as chief of post on their own. At the same time, when communicating with foreign guests and foreign businessmen, they should also maintain good interpersonal communication and interpersonal skills. In addition, they must be able to skillfully use modern office equipment and be competent for language services and secretarial work in foreign-related business activities of foreign trade and joint ventures. In today's economic globalization, its outstanding feature is intercultural communication. As a professional English, business English teaching is a combination of international business knowledge and English language, to cultivate talents with proficient English communicative ability and solid professional knowledge in business to adapt to the needs of China's reform and opening and development of the market economy. Because of the different political, economic environment and traditional customs, people's commercial values, consumer psychology and management habits are very different. Therefore, in the foreign-related activities, business people should not only face different political systems, legal systems and economic environment, but also encounter many commercial and cultural conflicts. The cultivation of business culture awareness is of great significance for successful foreign-related business activities, and is the key to the success of international business activities. Therefore, in Business English teaching, strengthening the cultivation of business culture awareness has been mentioned more and more important position. Language and culture are inseparable and depend on each other. If they do not understand the different customs of different countries, they may make mistakes when interacting with people from different countries. Therefore, the teaching mode is disadvantageous to the cultivation of the comprehensive quality of business English majors.

Comprehensive Knowledge Structure. Comprehensive knowledge structure refers to a solid foundation of English and extensive knowledge of business. Strong basic knowledge of English, including solid English language skills and strong oral communication skills. Extensive business knowledge including business operation and secretarial skills. The establishment of free trade zones, the modern service industry and the logistics industry require many foreign language talents, who will be active in the tourism, exhibition and trade industries. Therefore, in addition to mastering a solid foundation of English, business English talents should also have extensive knowledge about business in various fields, which is also the basic requirement of knowledge structure. Comprehensive business English is a kind of general business English, like English language and literature students at the basic stage of learning comprehensive English. Different from comprehensive English, the connotation of integrated business English includes knowledge in 
various fields of international business, such as international marketing, international trade, international finance, corporate governance, international economy, international investment. The comprehensive business English course for business English majors is an integrated course in Business English skills, whose main purpose is to train and improve the students' ability to use business English in a comprehensive way. This course is explained mainly by the language training and discourse analysis to improve students' English reading ability, understand the expression and characteristics of English styles, enlarge their vocabulary and be familiar with the commonly used sentence patterns in English, with the business English listening and speaking, reading, writing, translation and other language skills, and master basic knowledge of international business.

\section{Suggestions for Training Model of Business English Talents in the Context of Free Trade Zones}

Adjust Course Design. At present, the teaching content and teaching material structure of business English major are relatively single, and the courses related to business English major are too few. The real business English teaching materials are also rare, and the reference materials for the strategy of the free trade zone are almost zero. These problems have restricted the cultivation of business English multicultural talents. Such short teaching boards are not suitable for the training of talents in the implementation of the strategy. The business English curriculum should highlight the applied talents of language ability, broaden the caliber, strengthen practice, improve the quality of the principle, the ability to education as the core to ensure the realization of training with strong English communication skills and business practice ability business talents. Basic knowledge module, English knowledge module, English business knowledge module and secretarial knowledge module. In these modules, the English knowledge module is an important part of it. It emphasizes the training of basic language communicative competence. Business English majors should pay attention to basic English knowledge and basic skills in the course setting, and emphasize the cultivation of communicative competence. If you can strengthen the English reading, listening, writing, translation, pronunciation classes, etc., these are the important basic courses of this major. We should highlight the development of cross-border e-commerce services and entrepreneurial ability for students as the standard, the addition of cross-border electricity supplier courses. Focus on fostering free trade zone internationalization, complex cross-border electricity supplier personnel, should reflect the cross-border electricity supplier of the basic theoretical knowledge and practical knowledge of curriculum system, the creation of cross-border e-commerce theory and practical operation, cross-border e-commerce logistics and express delivery practices, network marketing, supplier and customer relationship management and cross-border electronic business English courses.

Strengthen Student Practice. In addition to the theoretical courses, students rarely have practice opportunities. Business English majors, in addition to mastering comprehensive English and business knowledge, should also be familiar with basic foreign trade processes. So far, the school has not built a foreign trade business process and a foreign trade process simulation laboratory, and has not yet established a proper school enterprise cooperative practice base. It is far from enough for students to seek practical opportunities when they are engaged in practical activities. Without practical experience, students can not quickly adapt themselves to the post after graduation. Sufficient theoretical knowledge also needs to be combined with proper practice. Teachers should combine classroom teaching with practice, improve students' learning interest and quality, and provide practical opportunities for students as much as possible. A series of simulated business activities held in the school regularly by the students as trade role, experience all aspects of trading activities, try to handle foreign-related business, to achieve the operation to use book knowledge to practice the purpose. At the same time, teachers should also encourage students to obtain relevant certificates during school, such as the Cambridge Business English primary certificate and College English four, six certificate, etc.. The school should also actively cooperate with the relevant enterprises outside the school, set up a number of internship bases, so that students can practice courses and graduation practice at these bases, to increase work experience, prepare for future work. Schools should set up training centers to provide students with foreign trade business process and foreign trade process 
simulation laboratory, so that they can practice after learning theory, exercise and improve their practical ability. Secondly, schools should strengthen foreign cooperation, establish school enterprise internship bases, and provide more practical opportunities for students. Finally, the school should actively carry out cooperation and exchanges with other countries, in the practice of sending students to the national social and cultural practice, thus further keenly aware of other countries.

Improve Teacher Resources. As the main part of the daily teaching work, the faculty should not only ensure the adequate quantity, but also improve their teaching level constantly. Only in this way can we effectively improve the quality and efficiency of personnel training. There are many limitations in the teaching staff of universities, which are manifested in the relatively small number of teachers, and the personal teaching ability of teachers needs to continue to improve. Therefore, the university must pay attention to the construction of the teaching staff in the training of business English professionals, and constantly increase the intensity of construction to ensure adequate professional teachers to teach. Schools and foreign languages departments should increase their investment in Business English teachers and hire regular foreign trade companies or business professionals to give lectures and training to business English teachers. The establishment of school enterprise cooperation training base, training base to study in the summer and winter vacation or regularly sent professional business English teachers, only to have the practical experience in teaching, they can be more targeted to adjust the teaching procedures improve the teaching content. Once again, the school can hire foreign trade companies and successful people or management personnel in the enterprise to enter the classroom and become part-time teachers. This can make up for the shortage of teachers' practical experience. At the same time, you can also consider running schools together. Through the introduction of cooperation with foreign universities, to improve business English teaching and research, further understand the development of English speaking countries, business English teaching and research curriculum, teaching methods. Their curriculum and teaching organizations reflect the advanced educational philosophy. Special attention should be paid to strengthening the understanding of teachers in countries and expanding teachers' understanding culture to establish a distinctive contingent of teachers. Universities should encourage business English teachers to take part in continuing education and improve their teaching ability and scientific research ability.

\section{Conclusion}

The construction of free trade zones has increased the demand for business English talents, and has put forward higher requirements for the quality of qualified personnel. It also puts forward higher standards for business English teaching. How to deliver more excellent business English talents for the construction of free trade zones is a topic we need to continue to answer.

\section{References}

[1] Sun Ming. A Study on College Business English Talents Cultivation under the Background of Free Trade Zone [J]. Journal of Tianjin \& TV University, 2016, 20(2): 65-67.

[2] Wang Heng, Liu Jian. On the Construction of System for Practical Ability of Regional Business English Talents [J]. Journal of Jixi University, 2013, 13(1): 78-79.

[3] Zhu Qing, Lai Liqun. Free trade business English professional curriculum [J]. Journal of Hunan City University (Natural Science), 2015, 24(4): 212-213.

[4] Kuang Zengjie. Thinking on innovation of cultivating mode of international business under background of China (Shanghai) pilot free trade zone [J]. Research in Teaching, 2017, 40(1): 87-91. 